\title{
Functionalized Mesoporous Silica with Very Large Pores for Cellulase Immobilization
}

\author{
Sandy Budi Hartono, ${ }^{\dagger}$ Shi Zhang Qiao, ${ }^{*}, \dagger$ Jian Liu, ${ }^{\dagger}$ Kevin Jack, ${ }^{\ddagger}$ Bradley P. Ladewig, ${ }^{\dagger,}$ \\ Zhengping Hao," and Gao Qing Max Lu*,† \\ ARC Centre of Excellence for Functional Nanomaterials, Australian Institute for Bioengineering and \\ Nanotechnology, The University of Queensland, St Lucia, QLD 4072, Australia, Centre for Microscopy and \\ Microanalysis, The University of Queensland, St Lucia, QLD 4072, Australia, Research Centre for \\ Eco-Environmental Sciences, Chinese Academy of Sciences, Beijing 100085, P. R. China, and Department of \\ Chemical Engineering, Faculty of Engineering, Monash University, Clayton, VIC 3800, Australia
}

Received: September 6, 2009

\begin{abstract}
Organo-functionalized FDU-12 type silicas exhibiting large pore sizes and ordered mesoporous structures were synthesized at low reaction $\left(15^{\circ} \mathrm{C}\right)$ and high hydrothermal $\left(160^{\circ} \mathrm{C}\right)$ temperatures via the co-condensation of tetraethoxysilane (TEOS) with a suite of organosilanes, i.e., 3-aminopropyltriethoxysilane (APTES), 3-mercaptopropyltrimethoxysilane (MPTMS), vinyltrimethoxysilane (VTMS), and phenyltrimethoxysilane (PTMS), in the presence of structure directing micelles formed using the surfactant pluronic F127 and the pore enlarging reagent trimethylbenzene (TMB). Small-angle X-ray scattering (SAXS) and transmission electron microscopy (TEM) confirmed that all synthesized materials possessed a face-centered cubic mesostructure (space group $F m \overline{3} m$ ), while nitrogen sorption analyses showed that the synthesized materials had extra large pores with cavity sizes of up to $25.4 \mathrm{~nm}$ and entrance sizes of up to $10.8 \mathrm{~nm}$. X-ray photoelectron spectroscopy (XPS) and ${ }^{13} \mathrm{C}$ solid-state magic-angle spinning nuclear magnetic resonance $\left({ }^{13} \mathrm{C}\right.$-MAS NMR) measurements verified the incorporation of the different organosilanes into the silica network and more importantly on the inner and outer surfaces of the materials. As-obtained mesoporous silicas were tested in protein immobilization studies using bovine serum albumin and the cellulose-hydrolyzing enzyme cellulase, which in itself is a mixture of three large enzymes. Enzyme immobilization efficiency, activity, and stability varied significantly with organic functionality due to size exclusion effects at pore entries, electrostatic and hydrophobic interactions between the organo-functionalized surfaces and the enzymes, and conformational changes of the enzymes which can occur on some of the material surfaces. As a result, phenyl (PTMS)- and thiol (MPTMS)functionalized FDU-12 mesoporous silicas had a very low adsorption capacity of proteins because of their small pore sizes. Amino (APTES)-functionalized FDU-12 mesoporous silica showed the highest adsorption amount of proteins yet the lowest activity of immobilized cellulase. Cellulase immobilization on vinyl (VTMS)functionalized FDU-12 mesoporous silica appeared to be the most promising approach, since it occurred with high efficiency, maintained enzyme activity, and provided temporal enzyme stability.
\end{abstract}

\section{Introduction}

Cellulose is one of the most abundant organic materials in the world, ${ }^{1-3}$ and the use of waste cellulose as a raw material for the production of ethanol is a very promising approach to meeting current and future energy demands in a sustainable way. Ethanol production via the enzymatic route is a two-step process: Initially, a mixture of cellulose-hydrolyzing enzymes breaks down the cellulose chains into glucose, which is subsequently converted into ethanol. The mixture of enzymes capable of cellulose hydrolysis is referred to as cellulase and comprises three large molecules, i.e., cellobiohydrolase (CBH), endobeta1,4-glucanase (EG), and beta-glucosidase (or cellobiase), ${ }^{2}$ which work synergistically during cellulose hydrolysis. The largest challenges in optimizing cellulosic ethanol production and hence increasing the feasibility of a large-scale industrial application are enzyme stability and reusability, as well as the high cost

* Corresponding authors. E-mail: s.qiao@uq.edu.au (S.Z.Q); maxlu@ uq.edu.au (G.Q.M.L).

Australian Institute for Bioengineering and Nanotechnology, The University of Queensland.

${ }^{\sharp}$ Centre for Microscopy and Microanalysis, The University of Queensland.

${ }^{\S}$ Monash University.

"Chinese Academy of Sciences. associated with the initial purification of the enzyme mix from natural sources. ${ }^{4}$ One approach to increase the performance of the enzymatic process is to immobilize the enzymes in/on solid supports which renders them reusable and hence reduces the enzyme-related operating costs. ${ }^{5}$

The past decade saw a large variety of mesoporous silicas being tested for their enzyme immobilization efficiency, ${ }^{6-12}$ since they displayed many characteristics that may be beneficial for such a purpose, i.e., high surface area, narrow pore size distribution, tunable pore size, and high chemical and mechanical stability. ${ }^{13-16}$ However, due to size exclusion effects occurring at the pore entries, most of these studies were limited to small proteins and enzymes. Recently, Takimoto et al. studied the immobilization of cellulase on mesoporous SBA-15 materials. ${ }^{17}$ They found that pore size and $\mathrm{pH}$ value played important roles in enzyme loading, and that enzyme activity was largely dependent on pore size. Larger pores allowed for more ready diffusion of the substrate to the active sites of the enzymes and also maintained a higher enzyme mobility/flexibility within the cavities, hence resulting in higher enzyme activity.

A different mesoporous silica, FDU-12, which exhibits a cubic pore structure (cavity and pore entrance size: 12.3 and $8.9 \mathrm{~nm}$, respectively), was reportedly used for the successful 
immobilization of lysozyme (hydrodynamic radius: $3.2 \mathrm{~nm}){ }^{18}$ Recently, an extra-large pore ordered mesoporous silica FDU12 with pore size up to $27 \mathrm{~nm}$ has been successfully synthesized. ${ }^{19}$ Its large pore size and three-dimensional pore connectivity present the material as a superior choice over MCM-41 and SBA-15 for the immobilization of large enzymes, especially with respect to mass transfer and pore blocking. ${ }^{20}$

However, previous reports showed that surface functionalization of the silica support materials is necessary prior to enzyme immobilization such that the interaction between the silica surface and enzyme is maximized, and a beneficial microenvironment for optimum catalytic activity of the enzyme is created. ${ }^{8,10}$ Generally, functionalized mesoporous silicas show higher protein/enzyme adsorption amount than nonfunctionalized ones, ${ }^{7,21}$ and in some cases, enzyme immobilization in/on functionalized mesoporous silicas results in higher enzyme activity compared to the free enzyme. ${ }^{9}$ Organic functionalization of mesoporous silica materials can be achieved using either of the following two approaches: postsynthesis grafting or co-condensation. ${ }^{22-24}$ A detailed physicochemical study of organo-functionalized large pore FDU-12 silicas obtained via the latter method is urgently needed because the preparation conditions for large pore FDU-12 materials differ significantly from those of other mesoporous silicas (with pore sizes $<10$ $\mathrm{nm}$ ); i.e., they need lower synthesis temperatures to expand pores in the presence of salt and pore extension agents, ${ }^{25}$ and it is difficult to extrapolate on their protein/enzyme immobilization behavior from studies performed on other mesoporous silicas.

In this paper, we present the synthesis of organo-functionalized large pore FDU-12 silicas via the co-condensation of tetraethoxysilane (TEOS) and various organosilica precursors, i.e., 3-aminopropyltriethoxysilane (APTES), 3-mercaptopropyltrimethoxysilane (MPTMS), vinyltrimethoxysilane (VTMS), and phenyltrimethozysilane (PTMS). Among others, pore structure, pore size, total surface area, zeta potential, and elemental composition of the resulting materials as well as protein/enzyme immobilization on these materials are discussed. The effects of organo-functionalization and the resulting structural changes on cellulase immobilization efficiency, activity, and stability are detailed and explained.

\section{Experimental Section}

2.1. Chemicals. Triblock poly(ethylene oxide)- $b$ poly(propylene oxide)- $b$-poly(ethylene oxide) copolymer $\left(\mathrm{EO}_{106} \mathrm{PO}_{70} \mathrm{EO}_{106}\right.$, pluronic F127, $\left.M_{\mathrm{n}}=13400\right)$, tetraethoxysilane (TEOS, 99\%), 1,3,5-trimethylbenzene (TMB), APTES (99\%), MPTMS (95\%), VTMS (98\%), PTMS (98\%), bovine serum albumin (BSA, 98\%), carboxymethyl cellulose (CMC), and Trichoderma reesei cellulase solution were purchased from Sigma-Aldrich Pty. Ltd., Australia. 3,5-Dinitrosalicylic acid (DNS, 98\%) and sodium metabisulfite (98\%) were obtained from Fluka Chemika, while sodium hydroxide (97\%), hydrochloric acid (32\%), and potassium chloride $(99.8 \%)$ were acquired from Ajax Finechem. All chemicals were used as received without further purification.

2.2. Synthesis of Nonfunctionalized and Organo-Functionalized Large Pore FDU-12 Materials. In a typical synthesis, $1 \mathrm{~g}$ of pluronic $\mathrm{F} 127$ and $5 \mathrm{~g}$ of $\mathrm{KCl}$ were dissolved in $60 \mathrm{~mL}$ of $2 \mathrm{M} \mathrm{HCl}$ at $15{ }^{\circ} \mathrm{C}$ (synthesis temperature) and stirred for $15 \mathrm{~min}$, before $1.2 \mathrm{~g}$ of TMB was added and stirring was continued for a further $6 \mathrm{~h}$ at this temperature. Then, $4.16 \mathrm{~g}$ of TEOS was added and stirring continued for $24 \mathrm{~h}$ at $15{ }^{\circ} \mathrm{C}$. The final molar ratio of reactants was 1 TEOS:0.0037 F127: $0.5 \mathrm{TMB}: 3.36 \mathrm{KCl}: 6 \mathrm{HCl}: 155 \mathrm{H}_{2} \mathrm{O}$. All of the solution along with the precipitate was then removed to an autoclave and heated at $160{ }^{\circ} \mathrm{C}$ (hydrothermal temperature) for $72 \mathrm{~h}$ for hydrothermal treatment. The product was filtered, dried in air at room temperature, and then washed three times at $60{ }^{\circ} \mathrm{C}$ for $6 \mathrm{~h}$ each using a mixture of ethanol and hydrochloric acid $(\mathrm{HCl})(250$ and $2 \mathrm{~mL}$, respectively) to remove the surfactant and the pore enlarging reagent. Pure mesoporous FDU-12 silica (denoted as PS) was synthesized using TEOS only, while the various organofunctionalized FDU-12 silicas were prepared using a mixture of TEOS and one of the following organosilanes: APTES, MPTMS, VTMS, or PTMS (molar ratio TEOS:organosilane = 15:1). Obtained organo-functionalized FDU-12 silicas were denoted as S-APTES (amine functionalization), S-MPTMS (thiol functionalization), S-VTMS (vinyl functionalization), and SPTMS (phenyl functionalization), respectively.

For some studies, materials without open pore structures (i.e., only exhibiting external surfaces) were required. They were obtained in a similar fashion to the open pore structured materials; however, the postsynthesis washing/surfactant extraction process was less rigorous such that the surfactant pluronic F127 (and possibly the pore enlarging reagent TMB) remained within the pores of the mesoporous materials, and thus the pores were inaccessible/unavailable for protein/enzyme immobilization. The quick postsynthesis rinse of as-obtained materials only removed acid and salt residues from the external surface.

2.3. Characterization. Small-angle X-ray scattering (SAXS) was performed using an Anton-Parr SAXSess small-angle X-ray scattering system $\left(\mathrm{Cu} \mathrm{K} \mathrm{K}_{\alpha}\right.$ radiation, $\left.40 \mathrm{kV}, 35 \mathrm{~mA}\right)$. Transmission electron microscopy (TEM) images were collected on a JEOL 1010 electron microscope at an electron beam acceleration voltage of $100 \mathrm{kV}$. Nitrogen sorption isotherms of the samples were obtained using a Quantachrome Quadrasorb SI analyzer at $77 \mathrm{~K}$. Samples were degassed overnight at $120{ }^{\circ} \mathrm{C}$ in a vacuum prior to all $\mathrm{N}_{2}$-sorption measurements. The surface area was calculated according to the Brunauer-Emmett-Teller (BET) model using data in the relative pressure range $p / p_{0}=$ $0.05-0.25$. The total pore volume was calculated from the $\mathrm{N}_{2}$ amount adsorbed at maximum $p / p_{0}(=0.99)$. The pore size distribution was calculated according to the Broekhoff-de Boer $(\mathrm{BdB})$ method using a spherical model ${ }^{26}$ i.e., cavity and entrance pore sizes were determined from the adsorption and desorption branches, respectively. X-ray photoelectron spectra (XPS) were recorded on a Kratos Axis Ultra instrument using a monochromatic Al K $\alpha$ X-ray source. Survey spectra in the range 0-1200 $\mathrm{eV}$ were recorded using a dwell time of $100 \mathrm{~ms}$, pass energy of $160 \mathrm{eV}$, steps size of $1 \mathrm{eV}$, and one sweep only. Higher resolution scans (280-292 eV) were conducted with lower pass energy (20 eV), higher sweep, and longer dwell time $(250 \mathrm{~ms})$. The elemental compositions of nonfunctionalized and organofunctionalized FDU-12 samples were determined from the XPS spectra. The $\mathrm{C} 1 \mathrm{~s}$ peak with a binding energy of $285 \mathrm{eV}$ was used as the reference peak. ${ }^{13} \mathrm{C}$ solid state cross-polarization magic-angle spinning nuclear magnetic resonance $\left({ }^{13} \mathrm{C}-\mathrm{CP}-\mathrm{MAS}\right.$ NMR) measurements were performed on a Bruker MSL-300 spectrometer operating at a frequency of $75.482 \mathrm{MHz}$ for ${ }^{13} \mathrm{C}$. The spectrometer was equipped with a $4 \mathrm{~mm}$ double air bearing, magic-angle spinning probe suitable for MAS experiments. The proton $90^{\circ}$ pulse time was $5.5 \mu \mathrm{s}$, the acquisition time was 45 $\mathrm{ms}$, the cross-polarization time was $2 \mathrm{~ms}$, and the relaxation delay was $3 \mathrm{~s}$. The spectrum width was $50 \mathrm{kHz}$, and 4000 data points were collected over 2000 scans. All spectra were referenced to the resonance of adamantane $(\delta=38.23 \mathrm{ppm})$, and samples were equilibrated to room temperature $\left(22^{\circ} \mathrm{C}\right)$ prior to all measurements. Zeta potential measurements were con- 
ducted at the indicated $\mathrm{pH}$ values (4.7-4.8) using a Malvern Zetasizer NanoZS instrument, while ultraviolet-visible (UV-vis) absorbance spectroscopy was performed using a JASCO-V550 instrument.

2.4. Bovine Serum Albumin (BSA) Adsorption. Nonfunctionalized and organo-functionalized FDU-12 materials were first degassed overnight at $120{ }^{\circ} \mathrm{C}$, and BSA was dissolved in $0.01 \mathrm{M}$ acetate buffer $(\mathrm{pH} 4.7)$ to prepare BSA stock solutions with various concentrations ranging from 0.1 to $20 \mathrm{mg} \cdot \mathrm{mL}^{-1}$. As much as $0.05 \mathrm{~g}$ of mesoporous silica was then mixed with $5 \mathrm{~mL}$ of each BSA solution, and the resulting suspensions were incubated in a water shaker for $24 \mathrm{~h}$ at room temperature (20 ${ }^{\circ} \mathrm{C}$ ) and $200 \mathrm{rpm}$ shaking speed. Suspensions were separated by centrifugation at $4750 \mathrm{rpm}$ and $20{ }^{\circ} \mathrm{C}$ for $20 \mathrm{~min}$. Pre- and postincubation BSA concentrations were determined using the characteristic UV-vis absorbance of BSA at $280 \mathrm{~nm}$ and the linear part of a $C_{\mathrm{BSA}}-A_{280 \mathrm{~nm}}$-standard curve collected prior to the adsorption experiments. The difference in the BSA amount in solution before and after adsorption was deemed equal to the amount of BSA adsorbed on the material. BSA adsorption isotherms were constructed via combinatorial analysis of BSA solution equilibrium concentration and BSA loading of the materials (mg of BSA/g of sample), and the data points were fitted using a Langmuir equation.

2.5. Cellulase Immobilization, Activity, and Stability. Commercially available Trichoderma reesei cellulase solution was used as the enzyme source and various dilutions of the enzyme mix were prepared using citrate buffer $(\mathrm{pH} 4.8)$. Prior to immobilization of the enzyme on the various FDU-12 silica samples, all samples were degassed at $120{ }^{\circ} \mathrm{C}$ overnight. 100-200 $\mathrm{mg}$ of each sample was then incubated at $4{ }^{\circ} \mathrm{C}$ for $24 \mathrm{~h}$ with $20 \mathrm{~mL}$ each of the various enzyme solutions after which the samples were centrifuged and filtered. Pre- and postincubation enzyme concentrations ( $C_{0}$ and $C_{t}$, respectively) were determined using a Bradford protein assay with BSA as the protein standard. ${ }^{27}$ Lastly, the enzyme loading (mg of cellulose/g of sample) was calculated from the difference in preand postincubation enzyme concentration and plotted vs the cellulose equilibrium concentration to give the adsorption isotherm. The data points were fitted using a Langmuir equation.

Cellulase activity was determined using the carboxymethyl cellulose (CMC) assay, ${ }^{28}$ which utilized a water-soluble derivative of cellulose (i.e., CMC) rather than the water-insoluble nonderivatized cellulose. This approach was used in order to minimize any obstacles to the accurate determination of enzyme concentration which may arise from heterogeneous substrates and in order to increase the substrate's diffusion into the pores and hence the contact between enzyme and substrate. CMC is readily hydrolyzed by the cellulase enzyme mix, thereby giving rise to glucose, which is a reducing agent and is readily detected using the 3,5-dinitrosalicylic acid (DNS) method. ${ }^{29}$ Briefly, a DNS reagent mix was prepared by mixing $10.6 \mathrm{~g}$ of DNS, $19.8 \mathrm{~g}$ of sodium hydroxide $(\mathrm{NaOH}), 30.6 \mathrm{~g}$ of potassium sodium tartrate, $7.6 \mathrm{~mL}$ of phenol, $8.3 \mathrm{~g}$ of sodium metabisulfite, and $1416 \mathrm{~mL}$ of distilled $\mathrm{H}_{2} \mathrm{O}$. Then, $0.5 \mathrm{~mL}$ of aqueous $\mathrm{CMC}$ solution (1 wt \%) was mixed with $0.5 \mathrm{~mL}$ of cellulase-containing solution (free enzyme, $100 \times$ dilution of commercial enzyme solution in citrate buffer; immobilized enzyme, $100 \mathrm{mg}$ of nonfunctionalized or organo-functionalized FDU-12 sample after the enzyme immobilization step in $5 \mathrm{~mL}$ of citrate buffer) and the hydrolysis reaction was allowed to proceed for $60 \mathrm{~min}$. Subsequently, $3 \mathrm{~mL}$ of DNS reagent mix was added and the mixture was boiled for 5 min upon which a red-brown color of varying intensity developed $\left(\lambda_{\max }=540 \mathrm{~nm}\right)$. This change in

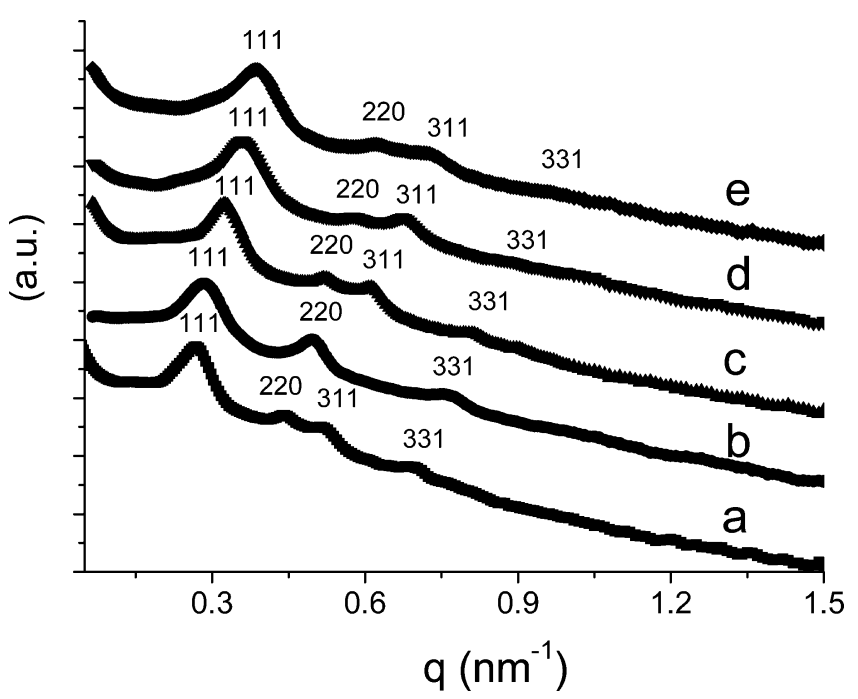

Figure 1. Small-angle X-ray scattering (SAXS) spectra of (a) nonfunctionalized and ( $b-e$ ) organo-functionalized FDU-12 silicas (SAPTES, S-VTMS, S-MPTMS, and S-PTMS, respectively). (VTMS, vinyltrimethoxysilane; PTMS, phenyltrimethoxysilane; MPTMS, 3-mercaptopropyltrimethoxysilane; APTES, 3-aminopropyltriethoxysilane).

color was attributed to the reduction-oxidation reaction of the DNS substrate with the glucose that was formed during the hydrolysis step, whereby the aldehyde group of the glucose was oxidized to a carbonyl group while DNS was reduced to chromophoric 3-amino-5-nitrosalicylic acid. The concentration of glucose present (which was proportional to the activity of the cellulase) was directly proportional to the intensity of the $\mathrm{UV}-$ vis absorbance band at $540 \mathrm{~nm}$. Blank experiments verified that nonfunctionalized and organo-functionalized FDU-12 silicas without immobilized enzymes did not produce glucose and that no DNS reduction was observed. Thus, it can be concluded that the enzyme activity that is observed solely originates from the immobilized cellulase enzyme mix.

The stability of immobilized enzymes was tested by storing the enzyme-loaded samples of nonfunctionalized and organofunctionalized FDU-12 silicas for 14 days in citrate buffer at 4 ${ }^{\circ} \mathrm{C}$. Samples with different cellulase loadings were chosen for the stability test. These samples were centrifuged to separately analyze the supernatant for any enzyme activity (which would indicate that the enzymes were released from the material) and the actual enzyme-loaded materials to determine whether enzyme activity deteriorated over this period of time. Enzyme concentrations were determined as described above.

\section{Results and Discussion}

3.1. Organo-Functionalized Mesoporous Silica with Large Pore. Nonfunctionalized and organo-functionalized mesoporous silica materials were prepared and characterized as described in the Experimental Section. Each organosilane affects the formation of the mesoporous silica matrix and its mesostructure differently. Figure 1 compares the SAXS spectra of the nonfunctionalized FDU-12 silica and the four organo-functionalized mesoporous silicas. The spectra of the organo-functionalized mesoporous silicas are very similar to that of the nonfunctional FDU-12 silica; i.e., they exhibit four main peaks, which can be indexed to the 111, 220, 311, and 331 crystal lattices. These peaks reflect an ordered, face-centered cubic (fcc) structure (space group $F m \overline{3} m$ ). ${ }^{19}$ However, the incorporation of the different organosilanes causes those peaks to shift to higher $q$-values in all spectra, which indicates a reduction in cavity 


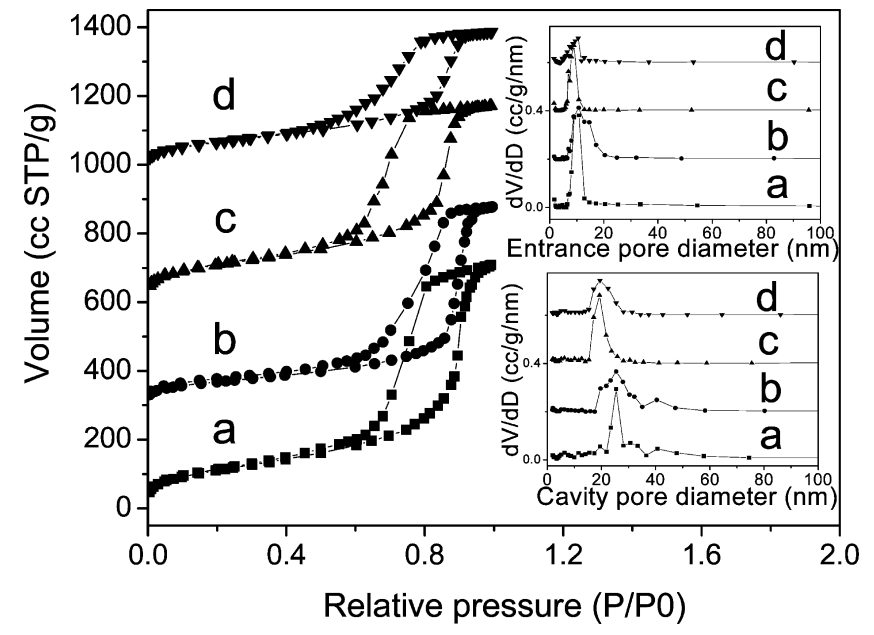

Figure 2. $\mathrm{N}_{2}$ sorption isotherms of (a) S-APTES, (b) S-VTMS, (c) S-MPTMS, and (d) S-PTMS (inset: cavity and entrance pore size distributions). For improved clarity, isotherms $b-d$ are shifted vertically by 300,600 , and $900 \mathrm{ccSTP} \cdot \mathrm{g}^{-1}$, respectively.

size for all organo-functionalized materials, but in some materials, it also causes a decrease in peak intensity, which indicates less ordered mesostructures. From the SAXS results, it can be concluded that (a) co-condensation of the organosilanes and TEOS still results in a FDU-12 type mesostructure and (b) PTMS, MPTMS, and VTMS functionalization all lead to smaller cavity sizes but only cause insignificant disruptions of the ordered mesoporous structure, while APTES functionalization results in a less ordered mesostructure and only slightly decreased cavity sizes.

The amine groups of APTES are readily protonated in acid conditions, ${ }^{30,31}$ and this protonation leads to disordered mesostructure in the synthesis of amine-functionalized SBA-15. ${ }^{30}$ Actually, the formation mechanism of large pore FDU-12 materials at low $\mathrm{pH}$ is similar to that of SBA-15; i.e., it follows a $\left(\mathrm{S}^{0} \mathrm{H}^{+}\right)\left(\mathrm{X}^{-} \mathrm{I}^{+}\right)$route. ${ }^{32,33}$ Therefore, the protonated amine group $\left(-\mathrm{NH}_{2} \mathrm{H}^{+}\right)$and the surfactant compete with each other to interact with the likewise protonated silanol groups $\left(-\mathrm{SiOH}_{2}{ }^{+}\right)$. Thereby, the protonated amine $\left(-\mathrm{NH}_{2} \mathrm{H}^{+}\right)$has a tendency to preferentially form $\left(-\mathrm{NH}_{2} \mathrm{H}^{+}\right)\left(\mathrm{X}^{-} \mathrm{SiOH}_{2}{ }^{+}\right)$complexes, which leads to less interaction between surfactant micelles and silicate, ${ }^{30}$ and hence less ordered mesostructures.

The nitrogen sorption isotherms of organo-functionalized FDU-12 samples, displayed in Figure 2, invariably show type IV isotherms with type H2 hysteresis loops which is typical for mesoporous materials with a cage-like structure. ${ }^{34}$ The relatively sharp increase of the adsorption isotherms at the higher end of the $p / p_{0}$ range indicates the occurrence of capillary condensation, hence confirming the uniform large pore structure of the samples. Cavity and entrance pore size distributions (Figure 2 insets) further confirm the presence of large pores in all materials. Structural parameters obtained from the adsorption isotherms are summarized in Table 1. Organo-functionalization of FDU-12 unequivocally results in reduced pore sizes compared to the nonfunctionalized material, with S-PTMS and S-MPTMS materials displaying the smallest cavity sizes of all organofunctionalized materials. S-APTES material exhibits the largest pore of the organo-functionalized materials with a cavity size of up to $25.4 \mathrm{~nm}$ and a pore entrance size of up to $10.8 \mathrm{~nm}$.

The decrease in the pore sizes of organo-functionalized mesoporous materials can be attributed to the strong hydrophobic interactions between organosilanes and the TMB, which is situated in the micelle core and usually causes micelle swelling (ergo larger pores in the final material). These interactions can lead to the extraction of a fraction of the TMB from the micelles, and thus less swelled micelles, which results in relatively smaller pore sizes and cell parameters. The addition of phenyl or thiol groups (PTMS and MPTMS functionalization) leads to materials with smaller cavity sizes compared to materials containing amino or vinyl groups (APTES and VTMS functionalization). This is due to the stronger hydrophobicity of phenyl and thiol moieties which can extract more fraction of TMB out of the micelles, thus contributing to larger pore size reductions. As discussed previously, the amino organoalkoxysilane precursor produces S-APTES material with a larger pore size due to the protonation effect of the amine group in acidic solution. This effect enhances the complexation of $-\mathrm{NH}_{2} \mathrm{H}^{+}$and $-\mathrm{SiOH}_{2}{ }^{+}$ but weakens the interaction between the amino precursor and TMB, which results in a smaller amount of TMB being extracted from the micelles, and hence larger pore sizes compared to the other organo-functionalized FDU-12 silicas (S-VTMS, SMPTMS, and S-PTMS).

Figure 3 displays the TEM images of organo-functionalized FDU-12 samples observed from two different directions (parallel and perpendicular to the pores). These images verify the presence of large pores and a relatively ordered mesostructure for the functionalized materials. Therefore, the TEM results are in agreement with the results of the $\mathrm{N}_{2}$ sorption measurements and the SAXS analyses; i.e., organo-functionalization of FDU12 silica maintains a fairly ordered fcc mesostructure.

XPS spectra can be used to determine the atomic configuration on sample surfaces. ${ }^{35}$ Figure 4 shows the XPS survey spectra of nonfunctionalized and organo-functionalized FDU12 materials that were used to determine the chemical structure and the elemental compositions (Table 1). In general, the spectra of organo-functionalized silica samples show relatively strong $\mathrm{C} 1 \mathrm{~s}$ and $\mathrm{Si} 2 \mathrm{~s}$ peaks which indicate the presence of organosilanes. The incorporation of APTES in the silica matrix results in a high intensity N1s peak in the S-APTES spectrum attributable to incorporated $\mathrm{NH}_{2}$ groups, while functionalization with $\mathrm{SH}$ groups via incorporation of MPTMS into the matrix results in S2s and S2p peaks in the S-MPTMS spectrum. The C1s peak observed in the FDU-12 pure silica spectrum can most probably be attributed to residual surfactant.

TABLE 1: Selected Physico-Chemical Properties, BSA Loading Capacity, and Elemental Composition of Nonfunctionalized (Pure Silica) and Organo-Functionalized FDU-12 Silicas (S-VTMS, S-PTMS, S-MPTMS, and S-APTES)

\begin{tabular}{|c|c|c|c|c|c|c|c|c|c|c|c|}
\hline sample & \multicolumn{2}{|c|}{ pore size $(\mathrm{nm})$} & $\begin{array}{l}\text { pore volume } \\
\quad(\mathrm{cc} / \mathrm{g})\end{array}$ & $\begin{array}{l}\text { BET surface } \\
\text { area }\left(\mathrm{m}^{2} / \mathrm{g}\right)\end{array}$ & $\begin{array}{c}\text { zeta potential } \\
\text { at } \mathrm{pH} 4.7(\mathrm{mV})\end{array}$ & $\begin{array}{c}\text { BSA loading } \\
\text { capacity at } \mathrm{pH} 4.7 \\
q_{\mathrm{m}}(\mathrm{mg} / \mathrm{g})\end{array}$ & \multicolumn{5}{|c|}{ elemental composition (at \%) } \\
\hline pure silica & 28.0 & 10.8 & 1.03 & 271 & -7.34 & 36.1 & 3.98 & 66.12 & 29.58 & 0.32 & 0.00 \\
\hline S-PTMS & 19.4 & 10.5 & 0.60 & 250 & -5.22 & 30.5 & 10.45 & 52.71 & 36.66 & 0.00 & 0.00 \\
\hline S-MPTMS & 19.3 & 9.0 & 0.88 & 394 & -0.31 & 6.2 & 16.17 & 48.14 & 33.80 & 0.00 & 1.89 \\
\hline S-APTES & 25.4 & 10.8 & 1.10 & 403 & +5.87 & 132.6 & 9.63 & 53.13 & 36.00 & 1.25 & 0.00 \\
\hline
\end{tabular}




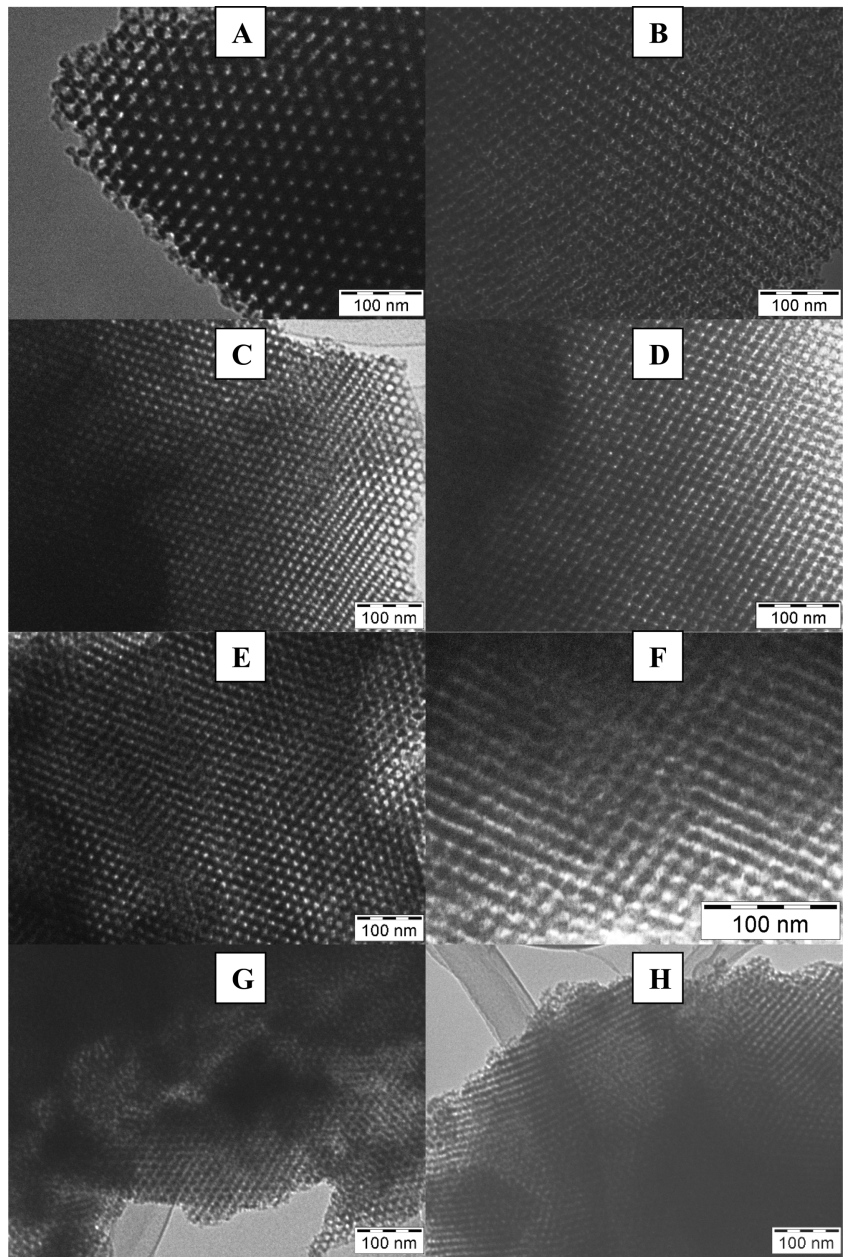

Figure 3. Transmission electron microscopy (TEM) images of (A, B) S-APTES, (C, D) S-VTMS, (E, F) S-MPTMS, and (G, H) S-PTMS

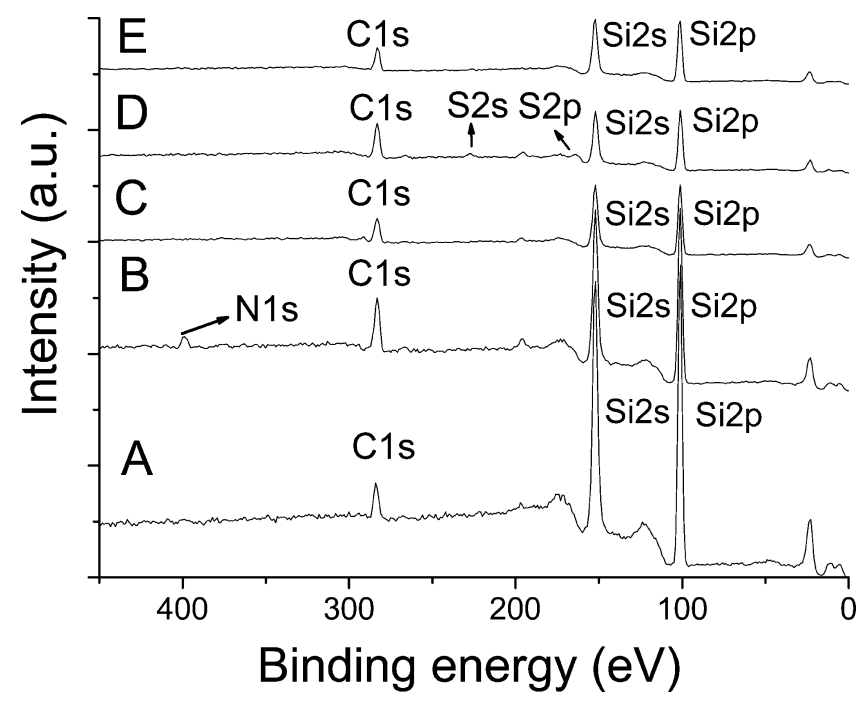

Figure 4. XPS survey spectra of (A) nonfunctionalized and (B-E) organo-functionalized FDU-12 silicas (S-APTES, S-VTMS, S-MPTMS, and S-PTMS, respectively).

Figure 5 displays the solid state ${ }^{13} \mathrm{C}$-CP-MAS NMR spectra of the various organo-functionalized FDU-12 samples. The three peaks in Figure $5 \mathrm{~A}$ at the chemical shifts 8.4, 25.2, and 40.7 ppm can be attributed to the carbon atoms $\mathrm{C}^{1}, \mathrm{C}^{2}$, and $\mathrm{C}^{3}$, respectively, of the aminopropyl group that is incorporated into the silica framework $\left(\mathrm{Si}-\mathrm{O}-\mathrm{Si}-\mathrm{C}^{1}-\mathrm{C}^{2}-\mathrm{C}^{3}-\mathrm{NH}_{2}\right)$ by cocondensation of APTES and TEOS. ${ }^{36-38}$ Peaks that resonate at around 64.1-78.0 ppm may be attributed to some surfactant remaining within the S-APTES sample. Other peaks, i.e., peaks at 15.6 and $57.3 \mathrm{ppm}$, can be assigned to carbon atoms of incompletely hydrolyzed ethoxy groups or ethanol residues from the extraction process. Similarly to the S-APTES spectrum, the spectrum of S-MPTMS (Figure 5C) shows signals attributable to the mercaptopropyl group carbon atoms (11.2 ppm $\left(\mathrm{C}^{1}\right), 25.5$ ppm $\left(\mathrm{C}^{2}\right)$, and $\left.22.1 \mathrm{ppm}\left(\mathrm{C}^{3}\right)\right)^{36}$ and signals attributable to unhydrolyzed ethoxy groups or residual ethanol (18.0 and 57.6 ppm). ${ }^{36,38}$ The vinyl moiety results in the observation of two resonance peaks (128 and $138 \mathrm{ppm})$ in the spectrum of the sample S-VTMS (Figure 5B). ${ }^{23}$ Likewise, the phenyl moiety of S-PTMS can be verified by the occurrence of two peaks (at 127 and $133.5 \mathrm{ppm}$ ) in its spectrum (Figure 5D). ${ }^{36}$ Both S-VTMS and S-PTMS contain some ethanol residues and also show signs of incomplete ethoxy group hydrolysis (15.6 and $56.8 \mathrm{ppm})$. Residual surfactant (69.2 ppm) is also observed in both samples. ${ }^{36}$

3.2. BSA Adsorption. Cellulase is quite a complex enzyme mixture. It consists of three different enzymes, i.e., CBH, EG, and cellobiase, all of which are of a different size. In order to achieve high enzyme activity of cellulase-loaded materials, the supporting materials must be able to immobilize all three of these enzymes and possibly all three of them to a similar extent. Prior to studying immobilization of this complex cellulase mixture on the FDU-12 materials, we studied the adsorption of BSA. BSA was chosen because of its comparatively large dimensions $\left(40 \times 40 \times 140 \AA^{3}\right)$, its high molecular weight $(69$ $\mathrm{kDa}){ }^{39}$ and its isoelectric point (around $\mathrm{pH}$ 4.7-4.9) which is similar to that of the three cellulase enzymes. ${ }^{39-43}$

As is evident from both the data listed in Table 1 and the adsorption isotherms displayed in Figure 6, S-APTES and S-VTMS materials exhibit the highest and second highest BSA adsorption capacity of all nonfunctionalized and organofunctionalized FDU-12 materials, respectively. This shows that pore size and surface characteristics significantly influence the ability of BSA to enter the pores and the interaction of BSA molecules with the material surfaces. At its isoelectric point $\mathrm{pH} 4.7$ (which was used to determine the adsorption isotherms), i.e., when intramolecular electrostatic repulsion is at its minimum, BSA is negatively charged $(-7.39 \mathrm{mV}$, determined by zeta potential measurement). This means that electrostatic attraction occurs between BSA and the S-APTES, which is positively charged at $\mathrm{pH} 4.7$ (Table 1), while electrostatic repulsion exists between BSA and the other nonfunctionalized and organo-functionalized FDU-12 silicas due to them carrying a negative charge at this $\mathrm{pH}$ (Table 1$)$. Thus, S-APTES can adsorb comparatively more BSA than the other FDU-12 materials, including the nonfunctionalized material. The small cavity and pore entry sizes of S-MPTMS and S-PTMS have a detrimental effect on the materials' capacity to adsorb BSA, leading to very small BSA adsorption amounts being observed. In contrast, the high BSA adsorption capacity of S-VTMS can probably be attributed to its large pore entrance and cavity sizes (relative to S-MPTMS and S-PTMS). However, when comparing nonfunctionalized and VTMS-functionalized FDU-12 materials, it has to be noted that the latter exhibits a similar pore entry size but a lower cavity size while still adsorbing higher amounts of BSA. The reason for this phenomenon is probably the hydrophobic interaction between certain (hydrophobic) protein domains and (hydrophobic) vinyl moieties. ${ }^{21,36}$

On the basis of these BSA immobilization results, APTESand VTMS-functionalized and nonfunctionalized FDU-12 materials were chosen as supporting materials for the cellulase 

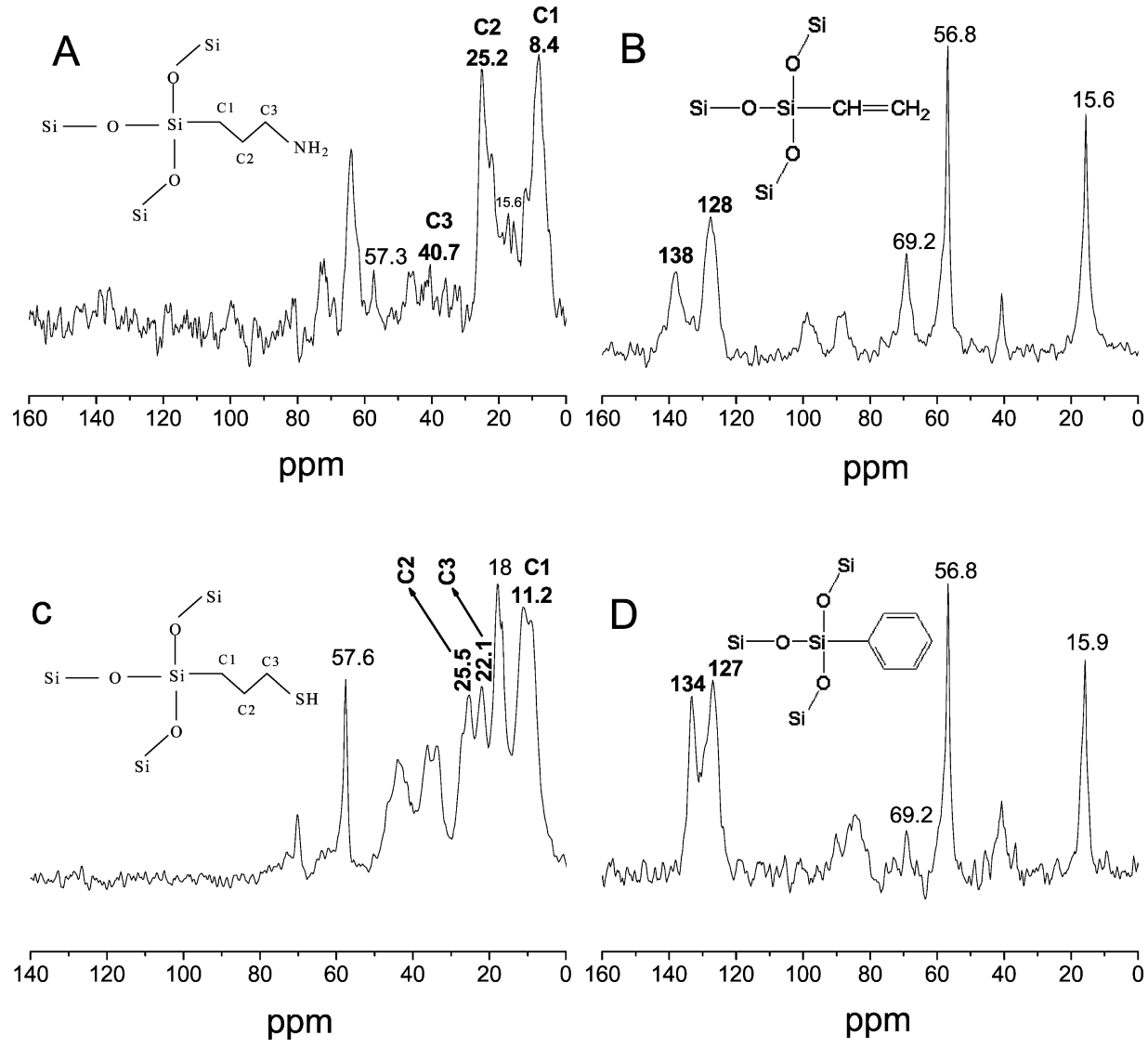

Figure 5. ${ }^{13} \mathrm{C}$ solid state cross-polarization magic-angle spinning nuclear resonance $\left({ }^{13} \mathrm{C}-\mathrm{CP}-\mathrm{MAS}\right.$ NMR $)$ spectra of organo-functionalized FDU12 silicas and assignment of ${ }^{13} \mathrm{C}$ chemical shifts to the corresponding structure elements: (A) S-APTES; (B) S-VTMS; (C) S-MPTMS; (D) S-PTMS.

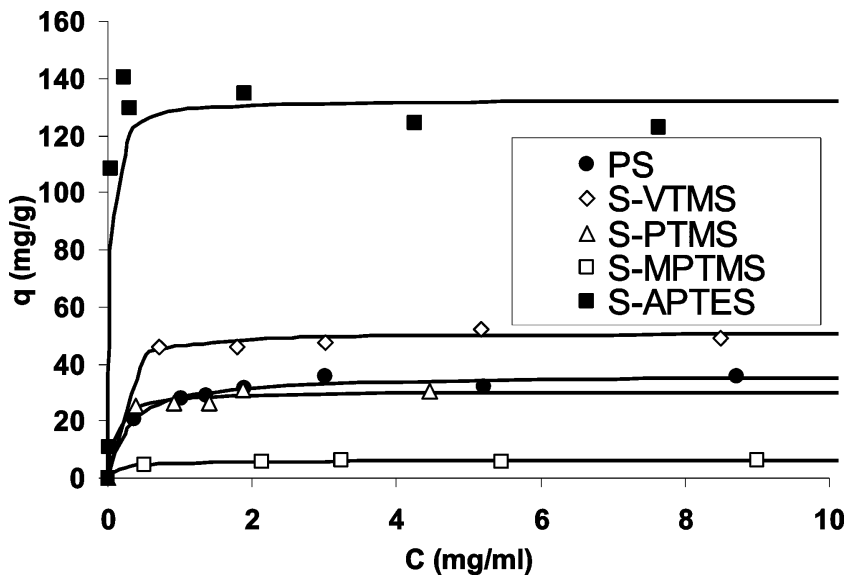

Figure 6. Adsorption isotherms of bovine serum albumin (BSA) on nonfunctionalized (pure silica, PS) and organo-functionalized FDU12 silicas (S-VTMS, S-PTMS, S-MPTMS, and S-APTES).

immobilization experiments. They exhibited the highest BSA adsorption capacities due to large pore entrance and cavity sizes and strong intermolecular interactions with the protein.

3.3. Cellulase Immobilization. Cellulase immobilization

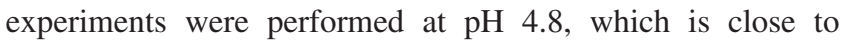
cellulase's isoelectric point of 4.75 and is also the optimum $\mathrm{pH}$ range for the free enzyme to reach its maximum activity. ${ }^{28}$ Table 2 and Figure 7 summarize the results of the cellulase immobilization experiments. As evident from the graphs and the values listed, S-APTES and S-VTMS exhibited similar cellulase adsorption capacities, which additionally were also larger than the adsorption capacity of nonfunctionalized FDU-12. Zeta potential measurements showed that cellulase was negatively
TABLE 2: Cellulase Loading Capacity and Zeta Potential Values of Nonfunctionalized (Pure Silica) and Selected Organo-Functionalized FDU-12 Silicas (S-VTMS and S-APTES) with Open and Blocked Pores

\begin{tabular}{lcc}
\hline \multicolumn{1}{c}{ sample } & $\begin{array}{c}\text { loading capacity } \\
\text { at } \mathrm{pH} 4.8, q_{\mathrm{m}} \\
\text { (mg of cellulase/ } \\
\mathrm{pH} \text { of silica) }\end{array}$ \\
\hline pure silica & $-5.8(\mathrm{mV})$ & $\begin{array}{c}\mathrm{g} \text { otential at } \\
\text { pure silica w/ blocked pores }\end{array}$ \\
S-APTES & -4.51 & 10.35 \\
S-APTES w/ blocked pores & +4.76 & 4.25 \\
S-VTMS & +2.28 & 21.80 \\
S-VTMS w/ blocked pores & -4.48 & 12.85 \\
& -4.96 & 18.19 \\
& & 10.74
\end{tabular}

charged at $\mathrm{pH} 4.8(-6.02 \mathrm{mV})$. At the same $\mathrm{pH}$, both VTMSfunctionalized and nonfunctionalized FDU-12 also possessed a negative charge (Table 2); thus, the larger cellulase adsorption amount of S-VTMS compared to pure FDU-12 can, similarly to the adsorption of BSA, be ascribed to hydrophobic interactions between the vinyl groups and the enzyme. It is noteworthy that contrary to the BSA adsorption experiments the opposite charge of S-APTES and cellulase did not result in a significantly higher cellulase adsorption for this material when compared to S-VTMS. To explain this phenomenon, one needs to keep in mind that cellulase comprises three large enzymes $(\mathrm{CBH}, \mathrm{EG}$, and cellobiase), ${ }^{2}$ ranging in size from 24 to $74 \AA$ (when spherical) or from $13 \times 79 \AA^{2}$ to $42 \times 252 \AA^{2}$ (when ellipsoidal), ${ }^{44}$ and each one of these three enzymes most definitely has its own isoelectric point. The detailed studies of these proteins revealed that EG and $\mathrm{CBH}$ can even be classified into several different families (e.g., EG I, EG V, CBH I, etc.) 


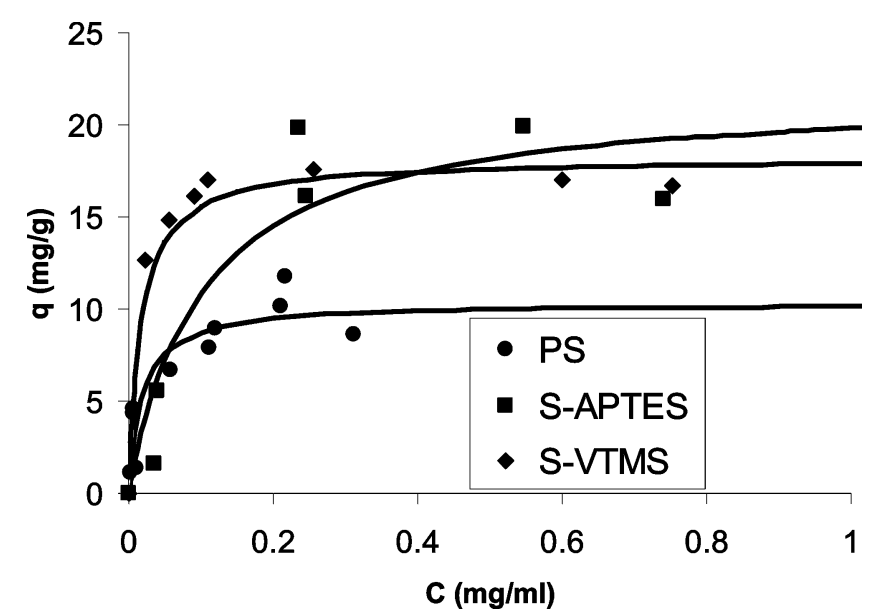

Figure 7. Adsorption isotherms of cellulase on nonfunctionalized (pure silica, PS) and selected organo-functionalized FDU-12 silicas (S-VTMS and S-APTES).

TABLE 3: Cellulase Activity before and after Immobilization on Nonfunctionalized (Pure Silica) and Selected Organo-Functionalized FDU-12 Silicas (S-VTMS and S-APTES) at Different Enzyme Loadings

\begin{tabular}{lccc}
\hline \multicolumn{1}{c}{$\begin{array}{c}\text { loading capacity, } \\
\text { sample }\end{array}$} & $\begin{array}{c}\text { enzyme } \\
\text { (mg of cellulase/ } \\
\text { g of silica) }\end{array}$ & $\begin{array}{c}\text { activity } \\
\text { of enzyme) } \\
\text { compared to } \\
\text { free enzyme }(\%)\end{array}$ \\
\hline free cellulase & & 14.00 & \\
pure silica & 4.35 & 1.64 & 11.71 \\
& 4.60 & 1.34 & 9.57 \\
& 6.71 & 10.55 & 75.32 \\
S-VTMS & 7.92 & 10.75 & 76.76 \\
& 8.55 & 9.98 & 71.25 \\
& 11.75 & 10.49 & 74.90 \\
& 7.38 & 9.86 & 70.43 \\
S-APTES & 12.63 & 10.36 & 74.03 \\
& 16.69 & 10.50 & 75.00 \\
& 17.05 & 10.94 & 78.15 \\
& 17.55 & 11.24 & 80.28 \\
& 1.60 & 0.48 & 3.44 \\
& 5.54 & 0.53 & 3.75 \\
& 15.99 & 1.09 & 7.77 \\
& 16.12 & 1.10 & 7.88 \\
& 19.05 & 2.18 & 15.57
\end{tabular}

each of which has a unique 3D structure and a specific isoelectric point. ${ }^{43}$ Thus, some of these enzymes may be positively charged at $\mathrm{pH} 4.8$, while the majority of enzymes are negatively charged, as is evident in the mixture's negative zeta potential at this $\mathrm{pH}$. This would mean that adsorption onto either positively or negatively charged carriers could be energetically favorable, and thus S-APTES (positive charge) and S-VTMS (negative charge) can both exhibit high cellulase adsorption capacities, as observed in our study.

Further cellulase adsorption studies were performed in order to elucidate the amount of cellulase that is adsorbed onto the external surface of the materials vs the amount adsorbed within the mesoporous structure of the materials. For this purpose, samples with blocked pore structures were synthesized as described in section 2.2. Cellulase adsorption experiments performed using these materials indicated that approximately $50 \%$ of the total cellulase amount immobilized by any material was adsorbed onto external surfaces (Table 2).

3.4. Activity of Immobilized Cellulase. The activity of free and immobilized cellulase (in nonfunctionalized and organofunctionalized FDU-12 materials) was tested using a CMC assay, as described in section 2.5. Table 3 summarizes the results of this study, in which nonfunctionalized and APTES- and

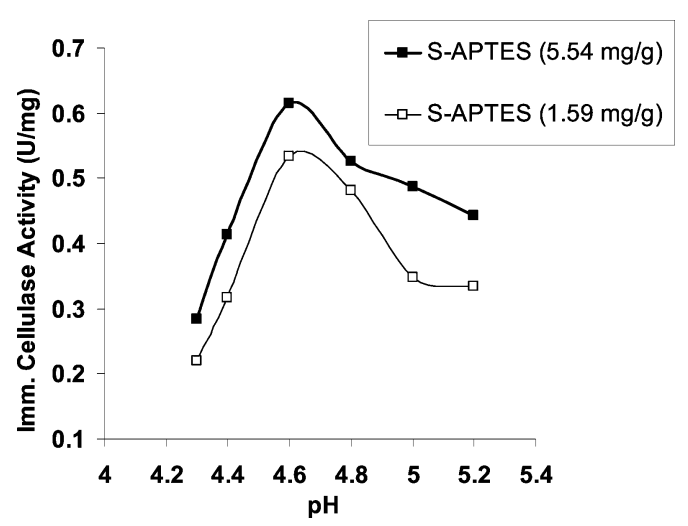

Figure 8. Analysis of the optimum $\mathrm{pH}$ value to achieve maximum catalytic activity of cellulase immobilized on APTES-functionalized FDU-12 silica (S-APTES) [samples differed in their initial cellulase loading $(1.59 \mathrm{mg} / \mathrm{g}$ or $5.54 \mathrm{mg}$ of enzyme/g of silica)].

VTMS-functionalized FDU-12 materials with different initial cellulose loadings were tested.

The functionalization of mesoporous FDU-12 silica not only affected the material's adsorption capacity but also played an important role in determining the activity of immobilized enzymes. The functional groups on the modified surfaces created a specific microenvironment, which can attract enzymes and/ or direct enzyme attachment onto the solid support. ${ }^{36}$ In our research, S-APTES showed the lowest immobilized enzyme activity, although it had the highest cellulase adsorption capacity. On the contrary, nonfunctionalized and VTMS-functionalized FDU-12 silicas were able to maintain a reasonably high cellulase activity upon enzyme immobilization. It was shown previously that high enzyme loadings did not always correlate with high enzyme activities. ${ }^{21}$

Surface functionalization of the carrier can cause a shift in the optimum $\mathrm{pH}$ value of enzyme activity at which maximum enzyme activity can be achieved. It has been reported that the optimum $\mathrm{pH}$ for cellulase can shift to lower $\mathrm{pH}$ values when the enzyme is immobilized on positively charged carriers. ${ }^{45}$ Therefore, the low enzyme activity observed for cellulase that was immobilized on S-APTES might have been caused by a shift in the optimum $\mathrm{pH}$ value. Thus, the effect of $\mathrm{pH}$ on the activity of cellulase immobilized on the material was studied. The results of this study are illustrated in Figure 8. It was found that cellulase immobilized on S-APTES showed the highest activity at $\mathrm{pH} 4.6$, which was slightly lower than the optimum $\mathrm{pH}$ for the free enzyme ( $\mathrm{pH} 4.8)$. However, even at this optimum $\mathrm{pH}$ of 4.6 , the activity of cellulase immobilized on S-APTES was still lower than that observed for nonfunctionalized or VTMS-functionalized FDU-12. There must thus be a different reason for the low activity observed.

The active sites of cellulase (exoglucanase/CBH and endoglucanase/EG) responsible for cellulose hydrolysis consist of many aspartic and glutamate acid residues. ${ }^{2}$ Both of these residues contain carboxylic acid functional groups, which can form amide bonds $(-\mathrm{C}(=\mathrm{O})-\mathrm{NH}-)$ with any primary amine (such as those on APTES-functionalized silica surfaces), thus strongly impairing enzyme activity. ${ }^{27,46}$ XPS analysis was used to determine the presence of the amide bonds. Figure 9 shows the $\mathrm{C} 1 \mathrm{~s}$ region of the high resolution XPS spectra of S-APTES samples with and without immobilized cellulase. For both samples, the $\mathrm{C} 1 \mathrm{~s}$ peak can be dissociated into five individual peaks (indexed C1, C2, C3, C4, and C5), ${ }^{46}$ which exemplify the five different binding states of the carbon atoms involved. The area under each peak can be expressed as a function of 

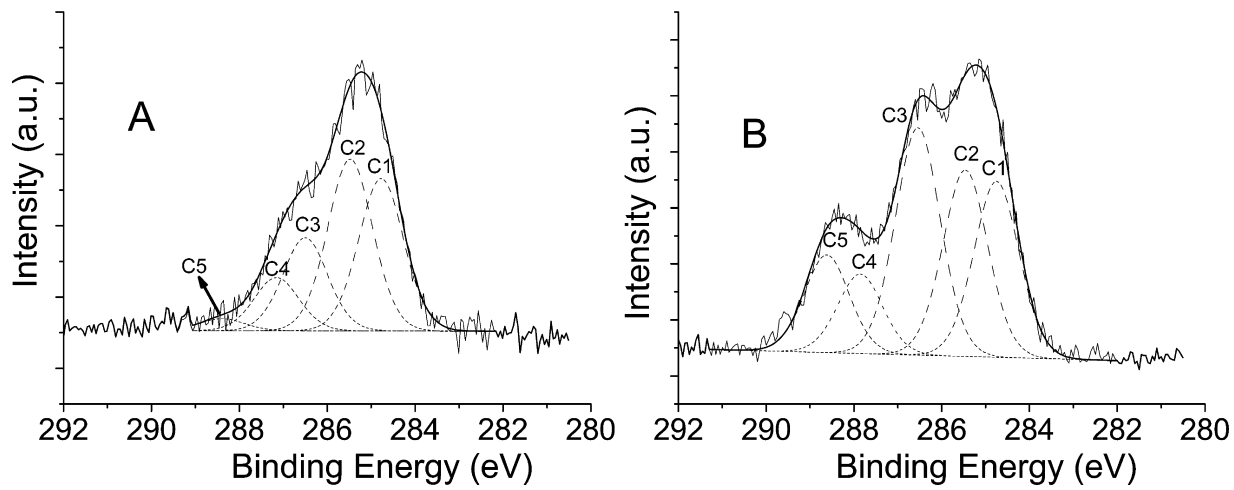

Figure 9. High resolution C1s XPS spectra of APTES-functionalized FDU-12 with (A) or without (B) immobilized cellulase (C1-C5 refer to different chemical binding states of the carbon atoms, as detailed in Table 4).

TABLE 4: Structural Assignment of the Various C1s Peaks Observed in the High Resolution X-ray Photoelectron Spectra (XPS) of APTES-Functionalized FDU-12 Silica (S-APTES) with and without Immobilized Cellulase (Spectra Shown in Figure 9)

\begin{tabular}{clccc}
\hline & & \multicolumn{2}{c}{$\begin{array}{c}\text { peak area relative to } \\
\text { total C1s peak area }(\%)\end{array}$} \\
\cline { 3 - 5 } & & & & $\begin{array}{c}\text { S-APTES w/ } \\
\text { immobilized } \\
\text { peak }\end{array}$ \\
\cline { 3 - 5 } & structure & $(\mathrm{eV})$ & S-APTES & cellulase \\
\hline C1 & $\mathrm{C}-\mathrm{Si}$ & 284.8 & 31.59 & 22.95 \\
$\mathrm{C} 2$ & $\mathrm{C}-\mathrm{H}$ & 285.5 & 35.59 & 24.33 \\
$\mathrm{C} 3$ & $\mathrm{C}-\mathrm{N}$ & 286.5 & 19.28 & 29.66 \\
$\mathrm{C} 4$ & $\mathrm{C}-\mathrm{O}-\mathrm{Si}$ & 287.2 & 11.02 & 10.34 \\
$\mathrm{C} 5$ & $\mathrm{O}=\mathrm{C}-\mathrm{NH}$ & 288.4 & 2.52 & 12.72
\end{tabular}

total peak area (\%), which is equivalent to the contribution of each of these peaks to the total peak (Table 4). The visual observation that the proportion of $\mathrm{C} 3$ and $\mathrm{C} 5$ increases upon cellulase immobilization (Figure 9B) is verified by an increase in the calculated peak area for these two peaks. This increase in $\mathrm{C} 3$ and $\mathrm{C} 5$ signal area is due to the formation of $-\mathrm{C}(=\mathrm{O})-\mathrm{NH}-$ bonds, ${ }^{46}$ and indicates that a reaction occurs between the protonated amines of the solid support and the carboxylic acids on some of the enzyme's amino acid residues. This reaction definitely impedes on at least some of the active sites of the cellulase enzymes and thus results in a low enzyme activity being observed for cellulase immobilized on APTESfunctionalized FDU-12 silica.

VTMS-functionalized FDU-12 silica behaved somewhat differently from the APTES-functionalized sample; i.e., it exhibited high enzyme loading capacity and activity. As discussed previously, the hydrophobic interaction between the cellulase and the S-VTMS support is the main reason for the high loading amount of cellulase, as the protein has a high affinity to hydrophobic surfaces. ${ }^{21,36}$ Further, the hydrophobicity of S-VTMS gives rise to a benign microenvironment for cellulase, beneficial to maintaining enzyme conformation and flexible mobility of the active sites. ${ }^{21}$ Nonfunctionalized FDU12 also maintains high cellulase activity, which means the low degree of hydrogen bonding that occurs between support and cellulase has no detrimental effect on the mobility of the enzyme's active sites.

3.5. Stability of Immobilized Cellulase. Immobilized enzyme stability is comprised of two factors: operational stability and storage stability. Operational stability refers to the extent to which immobilized enzymes maintain their catalytic activity, while storage stability is a term used to describe how well immobilized enzymes are protected from enzyme leakage. ${ }^{47}$ Both types of stability were elucidated over a 14-day period, as shown in Table 5.

In general, materials with higher enzyme loadings showed a greater tendency for enzyme leakage than those with initially lower loadings. The gradient between enzyme concentrations in the solid support and the surrounding solution induces very loosely bound enzymes to move to the solution, and the larger the gradient the more material is transferred. The silanol groups on the surface of nonfunctionalized FDU-12 silica only weakly interact with the enzymes via a few hydrogen bonds. This could be the reason why significant enzyme leakage $(7 \%)$ is observed for these materials. APTES- and VTMS-functionalized materials showed almost no enzyme leakage, with the small amount observed probably being due to the loss of initially aggregated enzymes from the external surface, ${ }^{48}$ which did not bind to/ interact with the organic moiety as the majority of the (nonag-

TABLE 5: Stability of Cellulase Immobilized on Nonfunctionalized (Pure Silica) and Selected Organo-Functionalized FDU-12 Silicas (S-APTES and S-VTMS) over a 14-Day Period

specific activity after 14 days relative to initial specific activity (\%)

\begin{tabular}{|c|c|c|c|c|c|c|}
\hline \multirow[b]{2}{*}{ sample } & \multirow[b]{2}{*}{$\begin{array}{c}\text { initial enzyme loading } \\
\text { (mg of cellulase/g of silica) }\end{array}$} & \multirow[b]{2}{*}{$\begin{array}{l}\text { enzyme leakage } \\
\text { over } 14 \text { days }(\%)\end{array}$} & \multirow[b]{2}{*}{$\begin{array}{l}\text { initial specific } \\
\text { activity (U/mg) }\end{array}$} & \multirow[b]{2}{*}{$\begin{array}{c}\text { specific activity } \\
\text { after } 14 \text { days (U/mg) }\end{array}$} & \multirow{2}{*}{\multicolumn{2}{|c|}{ adjusted for }} \\
\hline & & & & & & \\
\hline \multirow[t]{3}{*}{ pure silica } & 8.55 & 7.03 & 9.98 & 6.46 & 65 & 70 \\
\hline & 7.92 & 6.54 & 10.75 & 7.54 & 70 & 75 \\
\hline & 6.71 & 2.15 & 10.55 & 7.40 & 70 & 72 \\
\hline \multirow[t]{3}{*}{ S-APTES } & 19.83 & 1.03 & 1.24 & 0.99 & 78 & 81 \\
\hline & 16.12 & $a$ & 1.10 & 1.10 & 100 & 100 \\
\hline & 15.99 & $a$ & 1.09 & 0.96 & 88 & 88 \\
\hline \multirow[t]{3}{*}{ S-VTMS } & 17.55 & 2.24 & 11.24 & 7.95 & 71 & 73 \\
\hline & 16.69 & 1.74 & 10.50 & 9.41 & 90 & 91 \\
\hline & 12.63 & 0.93 & 10.36 & 7.37 & 71 & 72 \\
\hline
\end{tabular}

\footnotetext{
${ }^{a}$ No UV-vis absorbance detected.
} 
gregated) enzymes. Expectedly, the leakage of immobilized cellulase from the materials affected their specific enzyme activity (Table 5).

The operational stability of immobilized cellulase varied depending on the support it was immobilized on. Cellulase immobilized on nonfunctionalized FDU-12 retained 65-70\% of its initial activity (or 70-75\% after adjusting for leakage), while cellulase immobilized on S-VTMS and S-APTES retained $71-90 \%$ (or $72-91 \%$ after adjusting for leakage) and $78-100 \%$ (or $81-100 \%$ after adjusting for leakage), respectively, of its initial activity. Higher leaching of cellulase from nonfunctionalized FDU-12 materials obviously causes higher losses in activity compared to APTES- and VTMS-functionalized materials, but even after adjusting for enzyme leakage, the enzyme activity is still lower when cellulase is immobilized in the nonfunctionalized materials. Thus, the organo-functionalizaton increases not only cellulase retention but also cellulase stability.

\section{Conclusions}

Ordered, organo-functionalized FDU-12 mesoporous silicas with large cavity and pore entrance sizes were synthesized in a co-condensation approach using mixtures of TEOS (15 equiv) and different organosilanes (1 equiv) carrying amine, vinyl, thiol, or phenyl functionalities. Functionalization using this approach did not interrupt the ordered mesostructure, and the face-centered cubic porous structure was obtained in all syntheses. Pore entry size and cavity size influenced the adsorption of enzymes/ proteins on these materials, and so did the different surface characteristics introduced by the organosilanes. Electrostatic interactions between amino-functionalized surfaces and proteins/ enzymes played a key role in the high BSA and cellulase adsorption efficiencies observed for APTES-functionalized FDU-12, while the good adsorption capacity of VTMSfunctionalized material can be attributed to hydrophobic interaction between BSA/cellulase and the vinyl-functionalized surface of the material.

The activity of cellulase that was immobilized on APTESfunctionalized FDU-12 was weaker than that for cellulases immobilized on other supports due to changes in the enzyme's 3D conformation (caused by the formation of amide bonds between enzyme and solid support) which led to a loss of active sites and thus lower activity of the immobilized cellulase. The vinyl moiety in VTMS-functionalized materials exhibited a strong affinity for the cellulase and created a benign microenvironment for optimum enzyme activity, characterized by the ability to maintain a stable enzyme conformation and to maintain the mobility of the active sites.

In conclusion, surface functionalization of mesoporous silicas in combination with large pore sizes can result in an increase of enzyme immobilization efficiency, activity, and stability. This principle is promising for application in bioadsorption, biomolecule separation, enzyme catalysis, and drug and gene delivery.

Acknowledgment. This work was financially supported by the Australian Research Council (ARC) through the Discovery and Linkage Project programs (DP1095861, LP0882681) and the ARC Centre of Excellence for Functional Nanomaterials, and by The University of Queensland through a UQ Mid-Career Research Fellowship for S.Z.Q. Z.P.H. acknowledges financial support from the National Natural Science Fund of China (20725723). We thank Professor Andrew Whittaker and Dr. Ekaterina Strounina from The Centre for Magnetic Resonance, The University of Queensland, for NMR measurements and Dr. Barry Wood from The Brisbane Surface Analysis Facility, The University of Queensland, for XPS analyses.

\section{References and Notes}

(1) Kitaoka, M.; Taniguchi, H.; Sasaki, T. J. Ferment. Bioeng. 1989 , 67, 182-185.

(2) Bhat, M. K.; Bhat, S. Biotechnol. Adv. 1997, 15, 583-620.

(3) Bhat, M. K. Biotechnol. Adv. 2000, 18, 355-383.

(4) Xin, L.; Kumakura, M. Enzyme Microb. Technol. 1993, 15, 300303.

(5) Kim, J.; Grate, J. W.; Wang, P. Chem. Eng. Sci. 2005, 61, 10171026.

(6) Diaz, J. F.; Balkus, K. J., Jr. J. Mol. Catal. B: Enzym. 1996, 2 , $115-126$.

(7) Yiu, H. H. P.; Botting, C. H.; Botting, N. P.; Wright, P. A. Phys. Chem. Chem. Phys. 2001, 3, 2983-2985.

(8) Yiu, H. H. P.; Wright, P. A. J. Mater. Chem. 2005, 15, 36903700 .

(9) Lei, C.; Shin, Y.; Magnuson, J. K.; Fryxell, G.; Lasure, L. L.; Elliott, D. C.; Liu, J.; Ackerman, E. J. Nanotechnology 2006, 17, 5531-5538.

(10) Qiao, S. Z.; Yu, C. Z.; Xing, W.; Hu, Q. H.; Djojoputro, H.; Lu, G. Q. Chem. Mater. 2005, 17, 6172-6176.

(11) Qiao, S. Z.; Djojoputro, H.; Hu, Q. H.; Lu, G. Q. Prog. Solid State Chem. 2006, 34, 249-256.

(12) Budi-Hartono, S.; Qiao, S. Z.; Jack, J.; Ladewig, B. P.; Hao, Z. P.; Lu, G. Q. Langmuir 2009, 25, 6413-6424.

(13) Zhang, L.; Qiao, S. Z.; Jin, Y. G.; Yang, H. G.; Budihartono, S.; Stahr, F.; Yan, Z.; Wang, X.; Hao, Z. P.; Lu, G. Q. Adv. Funct. Mater. 2008, 18, 3203-3212.

(14) Hartmann, M. Chem. Mater. 2005, 17, 4577-4593.

(15) Vallet-Regi, M.; Balas, F.; Arcos, D. Angew. Chem., Int. Ed. 2007, 46, 7548-7558.

(16) Vinu, A.; Murugesan, V.; Tangermann, O.; Hartmann, M. Chem. Mater. 2004, 16, 3056-3065.

(17) Takimoto, A.; Shiomi, T.; Ino, K.; Tsunoda, T.; Kawai, A.; Mizukami, F.; Sakaguchi, K. Microporous Mesoporous Mater. 2008, 116, 601-606.

(18) Fan, J.; Yu, C.; Gao, F.; Lei, J.; Tian, B.; Wang, L.; Luo, Q.; Tu, B.; Zhou, W.; Zhao, D. Y. Angew. Chem., Int. Ed. 2003, 42, 3146-3150. (19) Fan, J.; Yu, C.; Lei, J.; Zhang, Q.; Li, T.; Tu, B.; Zhou, W.; Zhao, D. Y. J. Am. Chem. Soc. 2005, 127, 10794-10795.

(20) Shui, W.; Fan, J.; Yang, P.; Liu, C.; Zhai, J.; Lei, J.; Yan, Y.; Zhao, D. Y.; Chen, X. Anal. Chem. 2006, 78, 4811-4819.

(21) Chong, A. S. M.; Zhao, X. S. Catal. Today 2004, 93-95, 293299.

(22) Lim, M. H.; Stein, A. Chem. Mater. 1999, 11, 3285-3295.

(23) Chong, A. S. M.; Zhao, X. S.; Kustedjo, A. T.; Qiao, S. Z. Microporous Mesoporous Mater. 2004, 72, 33-42.

(24) Hoffmann, F.; Cornelius, M.; Morell, J.; Froba, M. Angew. Chem., Int. Ed. 2006, 45, 3216-3251.

(25) Zhou, X. F.; Qiao, S. Z.; Hao, N.; Wang, X.; Yu, C.; Wang, L.; Zhao, D. Y.; Lu, G. Q. Chem. Mater. 2007, 19, 1870-1876.

(26) Lukens, W. W.; Schmidt-Winkel, P.; Zhao, D. Y.; Feng, J. L.; Stucky, G. D. Langmuir 1999, 15, 5403-5409.

(27) Mao, X.; Guo, G.; Huang, J.; Du, Z.; Huang, Z.; Ma, L.; Li, P.;

Gu, L. J. Chem. Technol. Biotechnol. 2006, 81, 189-195.

(28) Ghose, T. K. Pure Appl. Chem. 1987, 59, 257-268.

(29) Miller, G. L. Anal. Chem. 1959, 31, 426-428.

(30) Chong, A. S. M.; Zhao, X. S. J. Phys. Chem. B 2003, 107, 1265012657.

(31) Walcarius, A.; Etienne, M.; Lebeau, B. Chem. Mater. 2003, 15, 2161-2173.

(32) Zhao, D. Y.; Feng, J.; Huo, Q.; Melosh, N.; Frederickson, G. H.; Chmelka, B. F.; Stucky, G. D. Science 1998, 279, 548-552.

(33) Zhao, D. Y.; Huo, Q.; Feng, J.; Chmelka, B. F.; Stucky, G. D. J. Am. Chem. Soc. 1998, 120, 6024-6036.

(34) Matos, J. R.; Kruk, M.; Mercuri, L. P.; Jaroniec, M.; Zhao, L.; Kamiyama, T.; Terasaki, O.; Pinnavaia, T. J.; Liu, Y. J. Am. Chem. Soc. 2003, 125, 821-829.

(35) Jin, Y. G.; Qiao, S. Z.; Diniz da Costa, J. C.; Wood, B. J.; Ladewig, B. P.; Lu, G. Q. Adv. Funct. Mater. 2007, 17, 3304-3311.

(36) Chong, A. S. M.; Zhao, X. S. Appl. Surf. Sci. 2004, 237, 398-404. (37) Qiao, S. Z.; Lin, C. X.; Jin, Y. G.; Li, Z.; Yan, Z.; Hao, Z. P.; Huang, Y.; Lu, G. Q. J. Phys. Chem. C 2009, 113, 8673-8682.

(38) Seifert, A.; Ladewig, K.; Schoenherr, P.; Hofmann, K.; Lungwitz, R.; Roth, I.; Pohlers, A.; Hoyer, W.; Baumann, G.; Schulze, S.; Hietschold, M.; Moszner, N.; Burtscher, P.; Spange, S. J. Sol-Gel Sci. Technol. 2010, $53,328-341$.

(39) Katiyar, A.; Ji, L.; Smirniotis, P. G.; Pinto, N. G. Microporous Mesoporous Mater. 2005, 80, 311-320.

(40) Ji, L.; Katiyar, A.; Pinto, N. G.; Jaroniec, M.; Smirniotis, P. G. Microporous Mesoporous Mater. 2004, 75, 221-229.

(41) Su, T. J.; Lu, J. R.; Thomas, R. K.; Cui, Z. F.; Penfold, J. J. Phys. Chem. B 1998, 102, 8100-8108.

(42) Tarasevich, Y. I. Theor. Exp. Chem. 2001, 37, 98-102. 
(43) Heikinheimo, L. Trichoderma reesei cellulases in processing of cotton. Ph.D. Thesis, Tampere University of Technology, 2002.

(44) Cowling, E. B.; Kirk, T. K. Biotechnol. Bioeng. Symp. 1976, 6, $95-123$

(45) Sudarmana, D. L. Continuos Hydrolysis of Cellobiose in an Immobilized Cellobiase Hollow Fiber Reactor. PH.D. Thesis, The University of Queensland, 1981.
(46) Wu, L.; Yuan, X.; Sheng, J. J. Membr. Sci. 2005, 250, 167173.

(47) Dincer, A.; Telefoncu, A. J. Mol. Catal. B: Enzym. 2007, 45, 1014.

(48) Sprey, B.; Lambert, C. Microbiol. Lett. 1983, 18, 217-222. 